\title{
Study Analysis on Failure Mechanism of Small Span Pedestrian Cold Formed Truss Bridge
}

\author{
Mohamad Ibrahim Zaed Ammar', Djoko Irawan', Data Iranata ${ }^{1}$, Budi Suswanto*, \\ ${ }^{1}$ Department of Civil Engineering, Institut Teknologi Sepuluh Nopember, Indonesia.
}

\begin{abstract}
Truss bridges are the structure whose load bearing superstructure are made up of truss shape. The purpose of this study is to investigate the failure mechanism of the cold formed steel truss bridge. Two truss bridge specimens called B1 and B2 were made with total length span of $4.8 \mathrm{~m}$, width of $0.85 \mathrm{~m}$, and height of $0.75 \mathrm{~m}$ for pedestrian bridge. Specimen B1 was made with connection using screw only and specimen B2 was made with connection using combination of screw and adhesive. The experimental programs have been conducted for Specimen B1 and B2 using bending test machine with twopoint loads. From the results of analytical solution and experimental program, they showed that the maximum load of specimen B1 is $3420 \mathrm{~kg}$ and specimen B2 is $5700 \mathrm{~kg}$. The failure mechanism of specimen B1 due to connection failure, the gusset plate experienced local buckling and some screws were broken and the failure mechanism of specimen B2 due to member failure, the compression member experienced local buckling and all connections were still in good condition. It can be concluded that specimen B2 is better performance than specimen B1 due to the contribution of combination of screw and adhesive on connection and adding the thickness of gusset plate.
\end{abstract}

Keywords - Adhesive, cold formed steel, connections, failure mechanism, screw, truss bridge

\section{INTRODUCTION}

Trusses are used in bridges to carry the gravity load of moving vehicles to the supporting sidewalks. From the definition of the bridge can be deduced that a bridge is an infrastructure that functions as a liaison between regions to pass through obstacles such as rivers, valleys, ravines, and so on. So that it is expected to accelerate the pace of development programs in various fields.

Bridge trusses are used in bridges to transfer gravity loads from moving vehicles to support platforms. Depending on the location and length of the span bridge, the truss can be either of through type or deck type. In the type through, the transport method is supported in the bottom cord of the trusses. In the deck bridge, the transport method is supported at the top of the trusses. Typically, the structural framework that supports the carriage path designed to transfer loads from the carriage method to the nodal points of vertical bridges. Many of them have exceeded the design age limit and need to be replaced or repaired. The growth of transportation, over-load cases and lack of maintenance caused many steel trusses bridges to be damaged have verified the by Lewis et al. in [1]. By observing large number of bridge failures, the common reasons can be noted as accidental overload and impact, force majeure (flood, earthquake etc.), structural design errors, construction supervision mistakes, and lack of maintenance. Imam and Chrysanthopoulos in [2] reviewed of metallic bridge failure statistics.

Chiorean in [3] developed a consistency model for the application of pushover analysis to investigate the configuration of damage to structural components can occur during period of construction or after completion period of construction or during the service life period, this can occur, among others, due to several factors including overloading, poor planning, material use that is not in accordance with requirements, errors in the implementation of work and environmental factors that have not been expected in advance. Yamaguchi et al. in [4] analyzed the post-member failure causes the dynamic behavior of the bridle bridge, and the displacement of dynamic behavior can override in the static behavior. for that reason, dynamic analysis would be appropriate to assess the behavior of the truss bridge after member failure.

Charnrit et al. in [5] studied comparison between analytical results and response of the truss bridges measured in the laboratory under the moving load of the car and this work is divided into three parts. The first part deals with how to design bridge models. The experimental programs dealt with the unexpected reversion behavior of the vertical deflection of the Warren truss models under the low speed of the moving loads. This behavior, however, cannot be detected by traditional and numerical methods of analysis. Further study is required to clarify the parameter affecting the recoil behavior of the Warren truncation model.

Manda and Nakamura in [6] studied some issues concerned with establishing the span ratio and the live load distribution affect structural safety and ductility for these truss bridges. The collapse process clarifies by the large deformation elastic plastic method. Although the collapse process is quite different depending on the live load distribution, the truss bridge collapsed due to plastic buckling or elastic buckling. It found that the truss bridge has plentiful safety against the design live loads when it is designed by the current design specification.

Astaneh in [7] presented the progressive collapse of steel truss bridges; the case of bridge collapse on August $1^{\text {th }}, 2007$ the 40 years old I-35W steel deck truss bridge over the Mississippi 
River in Minneapolis in USA was collapse. The cause of sudden collapse due to a connection at one of the gusset plate's failure. Corrosion of the gusset plate and increase load of the bridge was the possible cause of the collapse on the bridge. Pinho et al. in [8] focused on perform a pushover analysis is subject to the structure to increase monotonous lateral forces with constant distribution until reaching the target displacement. A pushover analysis performed for the continuous multi-length bridge carried out regarding traditional pushover methods, these innovative single-use methods can lead to the attainment of improved forecasts.

The performance of the connection is primarily dependent on the number of screws and the use of adhesive material. The first research conducted adhesive connection and self-drilling screw for roof truss connection. It enhances the capacity of the roof truss element and minimizes the fracture of the element [9].

Yong and Chen in [10] reported an experimental test for CFS with self-drilling screw subdued in single shear mode and tension mode. In this case, self-drilling screw expressed a better moment capacity and stiffness contrast to the conventional joint. Young and Yan in [11] investigated the CFS for roof sheeting in connection with a self-tapping screw at ambient and elevated temperature. It could be claimed that the failure of the connection is also proceeded by the alteration of temperature. The significant temperature may affect the direct failure of the structure.

Padmanaban and Suresh in [12] has conducted experimental study on use of cold formed steel sections as truss members, the presence of gusset plate and the bolts has increased the ultimate load carrying capacity of the truss by $33 \%$ of its original value. This result will be laid as a strong foundation for using roof trusses that are entirely made up of cold formed steel (CFS) sections. Komara et al. in [13] has conducted experimental program of tensile capacity of cold-formed steel connections using self-drilling screws and adhesive materials, it is showed that the combination of screw and adhesive in connection performed better strength rather than screw only.

From AISI Manual Cold-Formed Steel Design [14] and ColdFormed Steel Design [15], the strength of member in tension and compression can be calculated according to Eq. 1 to Eq. 4 .

$$
T_{\mathrm{n}}=A_{\mathrm{g}} F_{\mathrm{y}}
$$

where: $T_{n}=$ nominal strength in yield tension

$A_{g}=$ gross area of cross section

$F_{y}=$ yield stress

$$
T_{\mathrm{n}}=A_{\mathrm{n}} F_{\mathrm{u}}
$$

where: $T_{n}=$ nominal strength in ultimate tension

$A_{n}=$ net area of cross section

$F_{u}=$ tensile stress

$$
P_{\mathrm{n}}=A_{\mathrm{e}} F_{\mathrm{n}}
$$

$$
\begin{array}{ll}
\text { For } \lambda_{\mathrm{c}} \leq 1.5 & F_{\mathrm{n}}=\left(0.658^{\lambda_{\mathrm{c}}^{2}}\right) F_{\mathrm{y}} \\
\text { For } \lambda_{\mathrm{c}}>1.5 & F_{\mathrm{n}}=\left[\frac{0.877}{\lambda_{\mathrm{c}}^{2}}\right] F_{\mathrm{y}}
\end{array}
$$

where: $P_{n}=$ nominal strength in compression $A_{e}=$ effective area of cross section
$F_{n}=$ compressive yield stress

$$
P_{\text {cr }}=\frac{k \pi^{2} E t^{3}}{12\left(1-\mu^{2}\right) h}
$$

where: $P_{c r}=$ critical load

$k=$ buckling coefficient

$E_{t}=$ tangent modulus of elasticity

$\mu=$ poisson ratio

\section{EXPERIMENTAL PROGRAM}

The purpose of this study is to investigate the failure mechanism of the cold formed steel truss bridge. The experimental programs have been conducted for specimen B1 and B2 using bending test machine with two-point loads. The structural cold formed steel used CFS- C-75 G-550 with material properties and dimension as listed in Table 1 and depicted in Fig. 1.

Table 1. Material properties of CFS- C-75 G-550

\begin{tabular}{|l|c|}
\hline \multicolumn{1}{|c|}{ Parameter } & Nominal \\
\hline Nominal grade & $550 \mathrm{MPa}$ \\
\hline Nominal thickness & $1.0 \mathrm{~mm}$ \\
\hline Volume weight & $7850 \mathrm{~kg} / \mathrm{m}^{3}$ \\
\hline Modulus of Elasticity & $200,000 \mathrm{MPa}$ \\
\hline Yield stress $\left(F_{y}\right)$ & $550 \mathrm{MPa}$ \\
\hline Ultimate stress $\left(F_{u}\right)$ & $600 \mathrm{MPa}$ \\
\hline Yield strain & 0.0045 \\
\hline Ultimate strain & 0.0286 \\
\hline
\end{tabular}

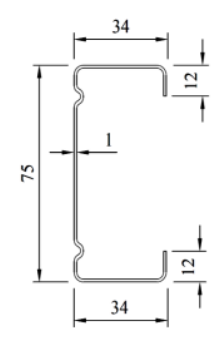

(a) Cross section $\mathrm{C}$

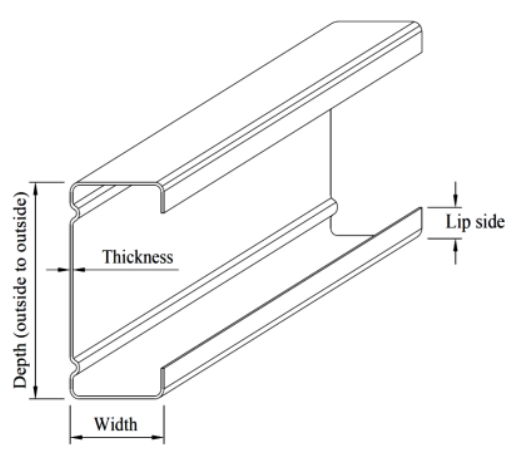

(b) Isometry view
Fig 1. Section geometry and dimension of CFS section (unit: $\mathrm{mm}$ )

Two Warren type truss bridge specimens called B1 and B2 were made with total length span of $4.8 \mathrm{~m}$, width of $0.85 \mathrm{~m}$, and height of $0.75 \mathrm{~m}$ for pedestrian bridge with the same scheme as shown in Fig. 2. Specimen B1 was made using screw only for connection with thickness of gusset plate is $1 \mathrm{~mm}$ and specimen B2 was made using combination of screw and adhesive of Sikadur $31 \mathrm{CF}$ Normal for connection with thickness of gusset plate is $3 \mathrm{~mm}$ as shown in Fig. 3 . 


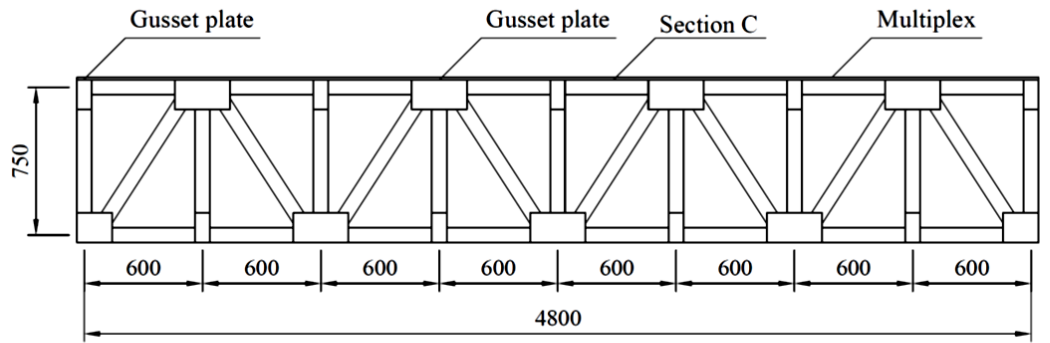

(a) Side View

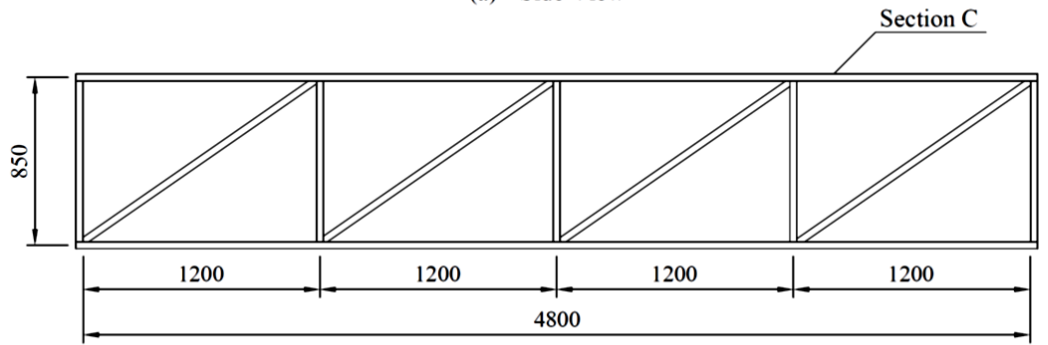

(c) Top View

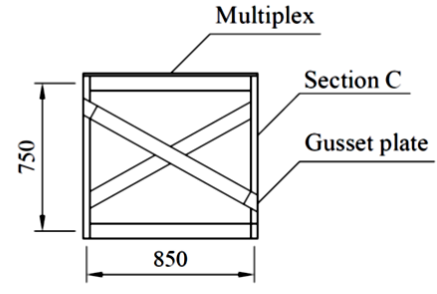

(b) Front View

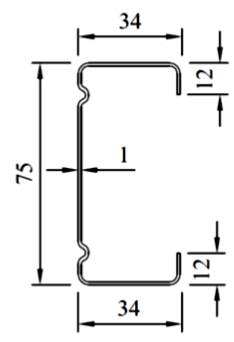

(d) Section C

Fig 2. Scheme of specimen B1 and B2

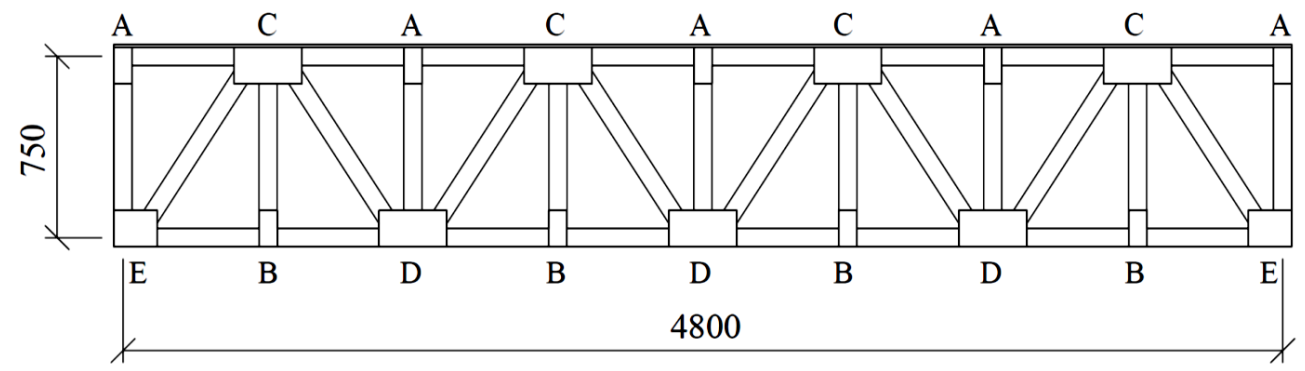

(a) Type of connection

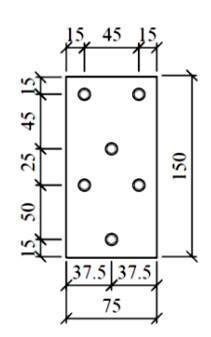

(b) Type A

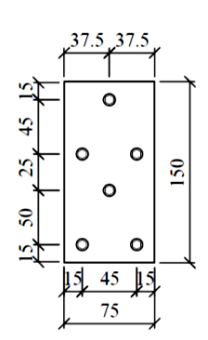

(c) Type B

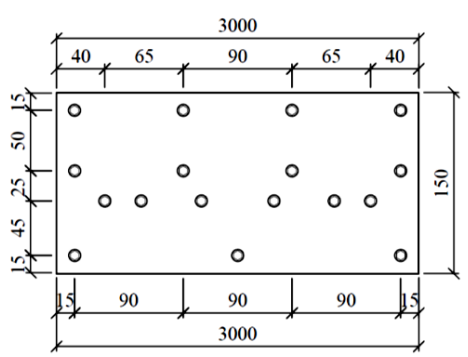

(d) Type C

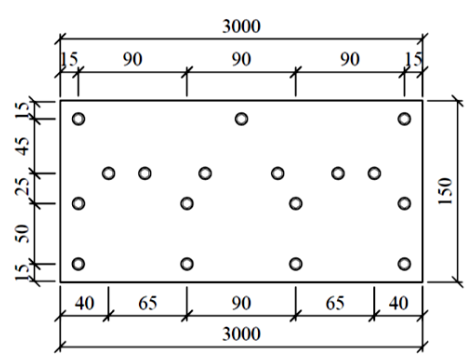

(e) Type D

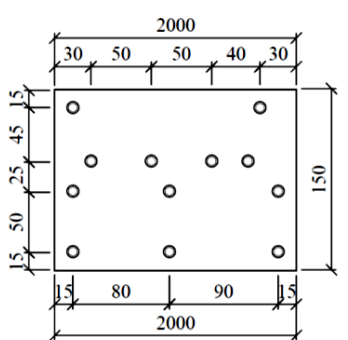

(f) Type E

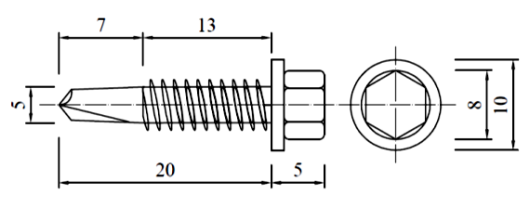

(g) Detail of screw

Fig 3. Detail of screw connection on gusset plate 


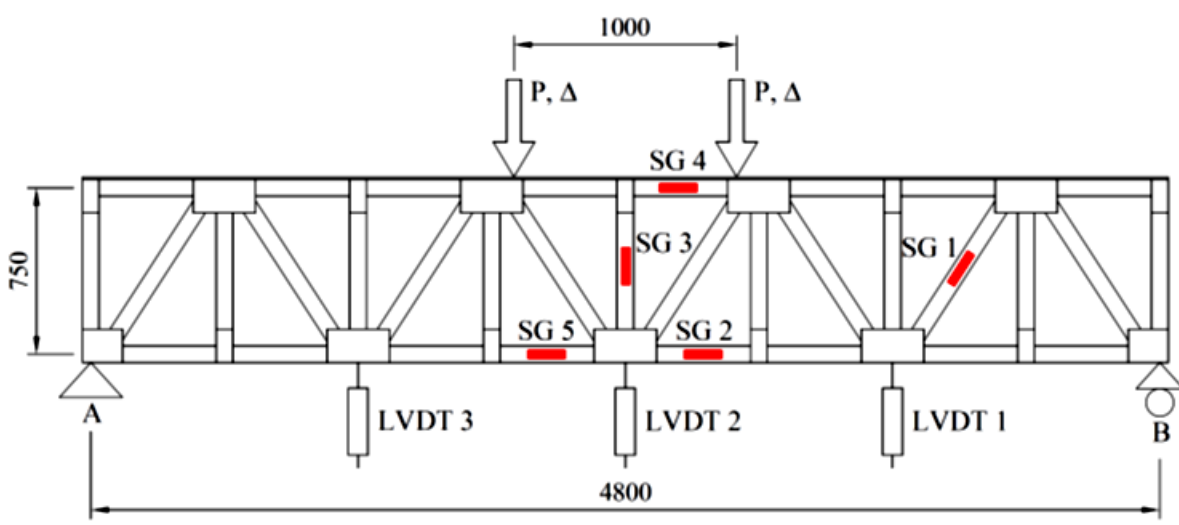

(a) Side View

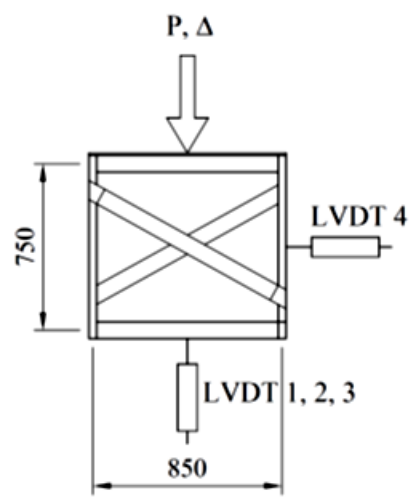

(b) Front View

Fig 4. Test setup scheme of specimen B1 and B2

The test setup of specimen B1 and B2 showed in Fig. 4, twopoint loads with distance $1 \mathrm{~m}$ were acting by using bending test machine with 100 tf capacity. The loading tests consisted of static loading test using force control. Several instruments were used to monitor the specimens during the loading test. The instruments such as data logger, 4 displacement transducers (LVDT), and 5 strain gauges, were used to monitor force, displacement, and strain of Specimen B1 and B2 during static loading test until experienced collapse structure. The documentation of test setup of Specimen B1, specimen B2, LVDT, and strain gauge showed in Fig. 5 to Fig. 8, respectively.

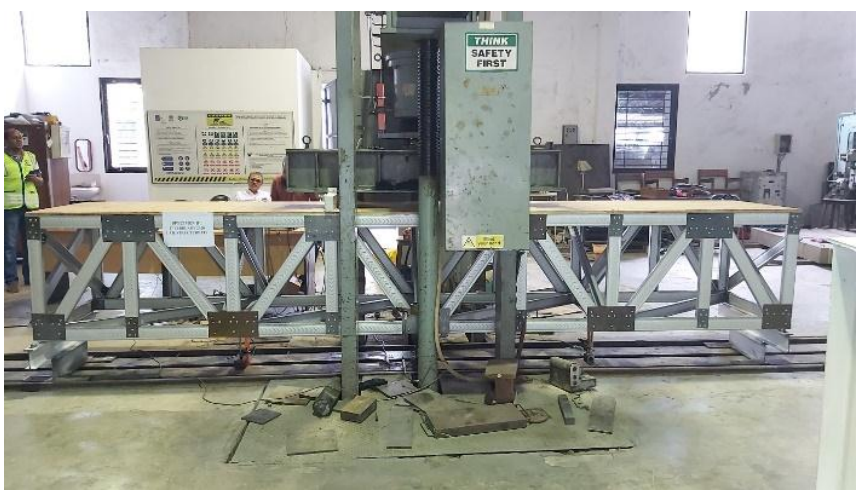

Fig 5. Test setup of specimen B1

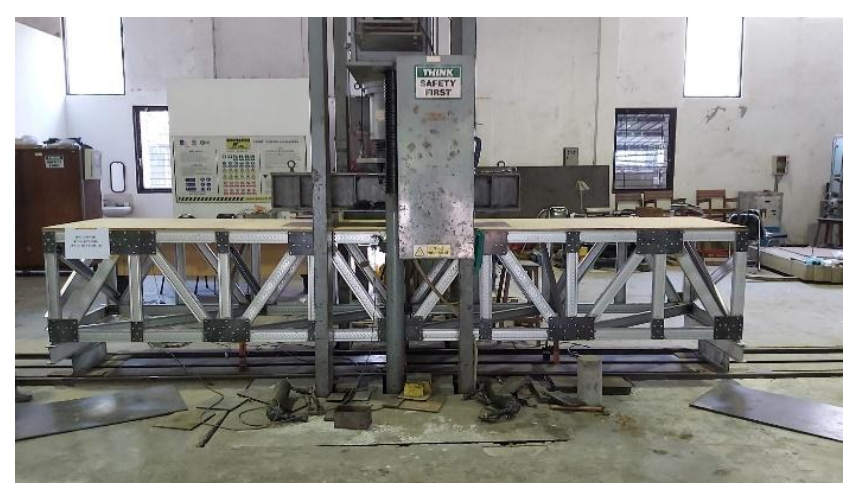

Fig 6. Test setup of specimen B2

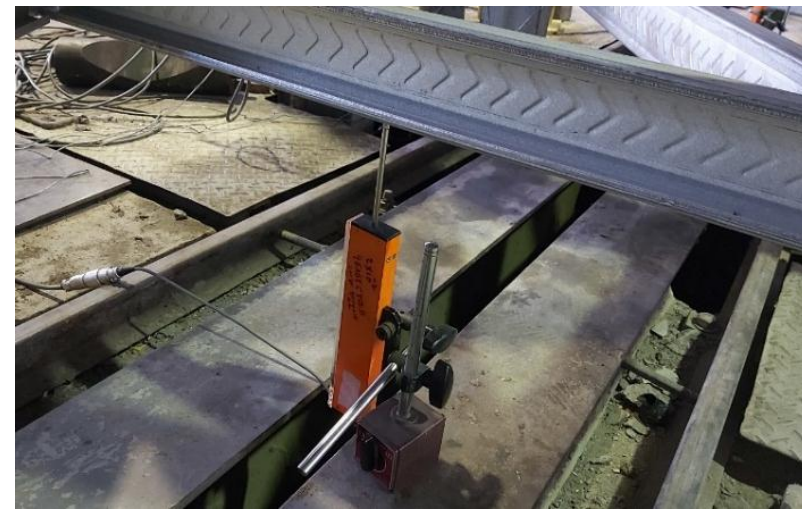

Fig 7. Position of LVDT on specimen B1 and B2

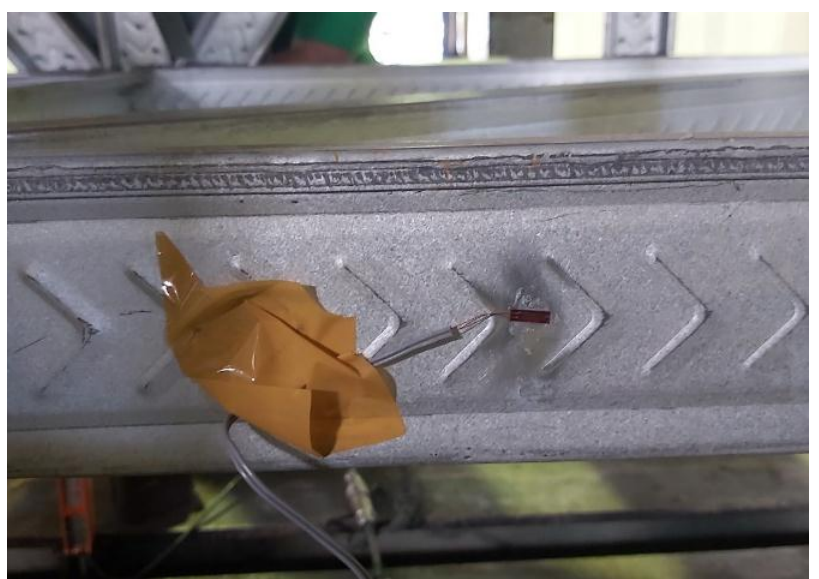

Fig 8. Position of strain gauge on specimen B1 and B2

\section{RESULTS AND DISCUSSION}

The experimental programs have been conducted for specimen B1 and B2 using bending test machine with force control until ultimate load. The deformed shape after reaching ultimate load of specimen B1 and B2 showed in Fig. 9 and Fig. 10, respectively. The failure mechanism of specimen $\mathrm{B} 1$ due to connection failure, the gusset plate experienced local buckling and some screws were broken as shown in Fig. 11. The failure mechanism of specimen B2 due to member failure, the compression member experienced local buckling and all 
connections were still in good condition as shown in Fig. 12.

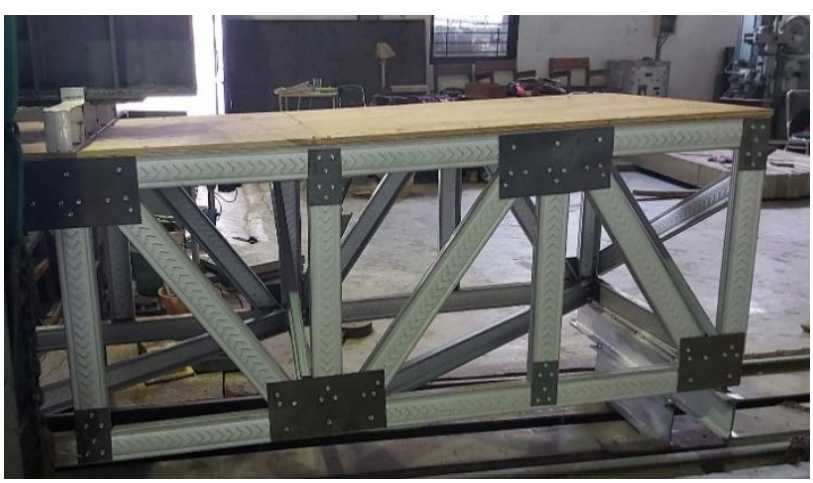

Fig 9. Condition of specimen B1 after testing

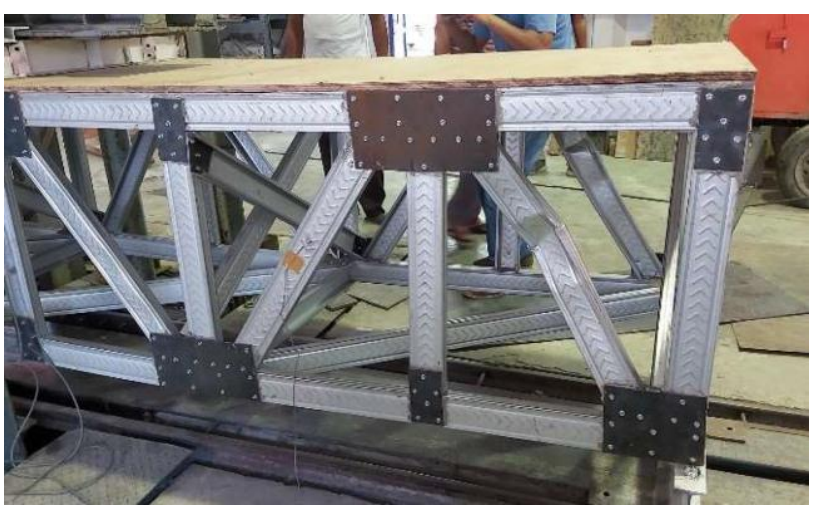

Fig 10. Condition of specimen B2 after testing

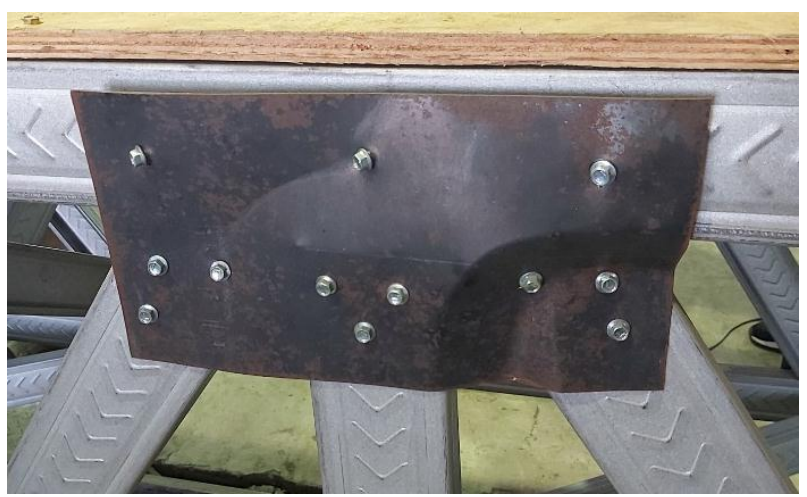

Fig 11. Condition of connection at specimen B1 after testing

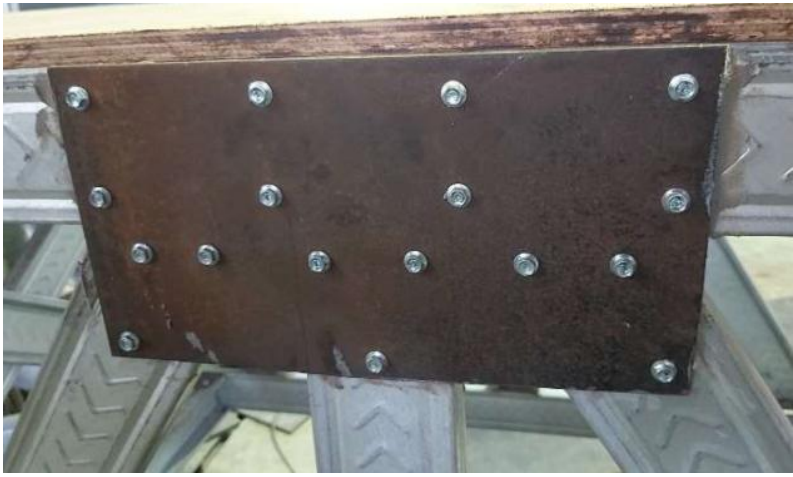

Fig 12. Condition of connection at specimen B2 after testing

From the test results of experimental program, they showed that the ultimate load of specimen B1 is $3420 \mathrm{~kg}$ at displacement $33.5 \mathrm{~mm}$ and specimen B2 is $5700 \mathrm{~kg}$ at displacement $28.3 \mathrm{~mm}$ as depicted in Fig. 13 and Table 2. Failure mechanism of specimen B1 occurred on connection, gusset plate buckling and screw broken, but for specimen B2 occurred on member buckling and connection is still in good condition.

Specimen B2 showed better performance than specimen B1, the ultimate load of specimen B2 is higher 1.667 time than load of specimen B1, and displacement of specimen B2 is lower 0.845 time than displacement of specimen B1. In addition, specimen B2 performed stiffer than specimen B2 due to connection on specimen B2 after testing is still in good condition, but connection on specimen B1 after testing experienced local buckling on gusset plate and some screws already broken.

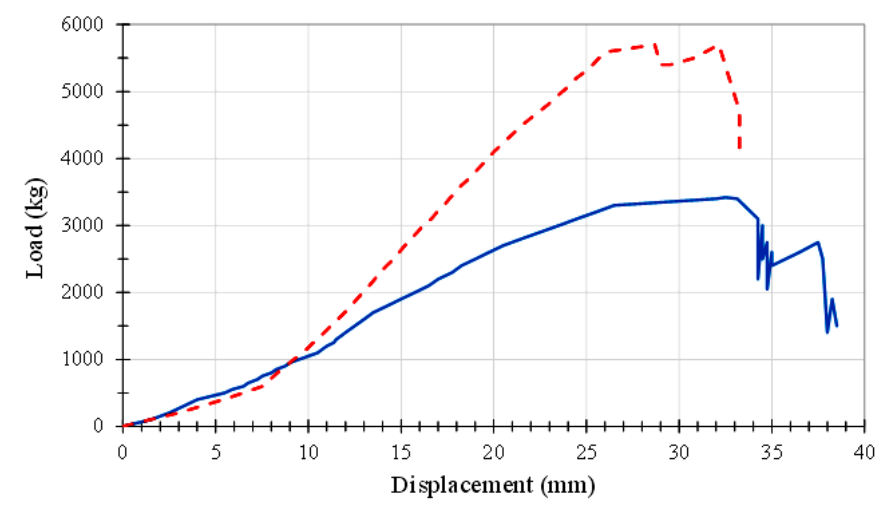

- Specimen B1 - - Specimen B2

Fig 13. Load vs Displacement curve of specimen B1 and B2

Table 2. Comparison of Force vs Displacement curve of specimen B1 and B2

\begin{tabular}{|c|c|c|c|c|c|}
\hline Specimen & $\begin{array}{c}\text { Ultimate } \\
\text { Load } \\
(\mathbf{m m})\end{array}$ & $\begin{array}{c}\text { Comparison } \\
\text { Load B2/B1 }\end{array}$ & $\begin{array}{c}\text { Displacement } \\
\mathbf{( m m})\end{array}$ & $\begin{array}{c}\text { Comparison } \\
\text { Displacement } \\
\text { B2/B1 }\end{array}$ & Failure Mechanism \\
\hline B1 & 3420 & \multirow{2}{*}{1.667} & 33.5 & & $\begin{array}{l}\text { Connection (gusset plate } \\
\text { buckling and screw broken) }\end{array}$ \\
\cline { 1 - 1 } B2 & 5700 & & 28.3 & 0.845 & $\begin{array}{l}\text { Member buckling (connection } \\
\text { in good condition) }\end{array}$ \\
\hline
\end{tabular}


Fig. 14 and Fig. 15 showed Force vs Strain curve of specimen B1 and B2, respectively, they showed that all strains are still in elastic range, because all strains are less than $4500 \mu \varepsilon$ as yield strain of CFS- C-75 G-550.

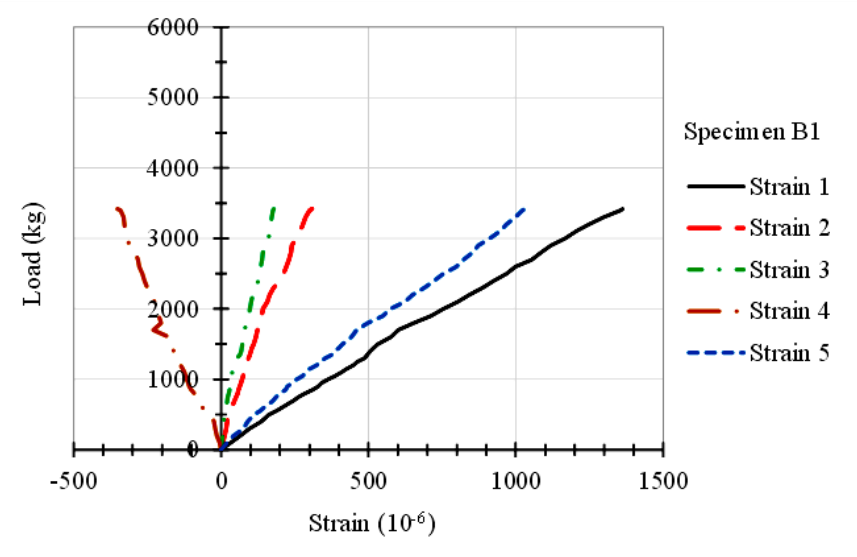

Fig 14. Force vs Strain curve of specimen B1

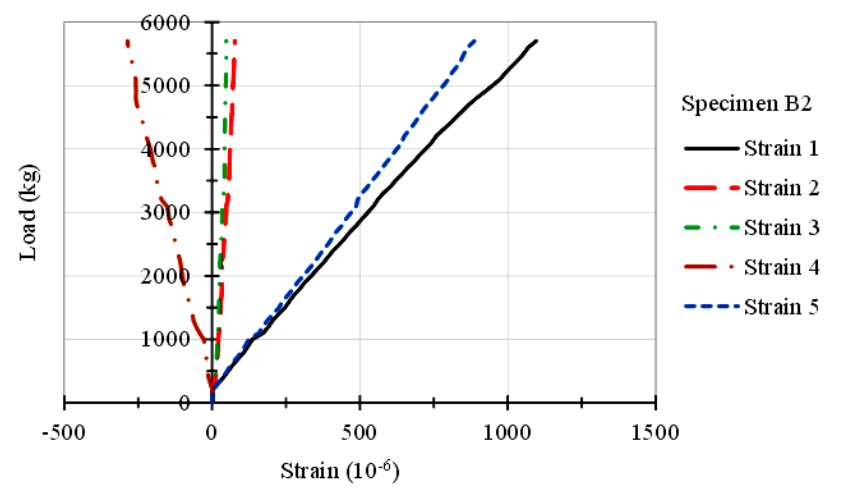

Fig 15. Force vs Strain curve of specimen B1

It can be concluded that specimen B2 is better performance than specimen B1 due to the contribution of combination of screw and adhesive on connection. By adding of thickness of gusset plate and combination screw and adhesive on gusset plate can make specimen B2 is stronger and stiffer than specimen B1, and it can make the connections are stronger than members capacity.

\section{CONCLUSIONS}

From the results of analytical solution and experimental program, they showed that:

1. The maximum load of specimen B1 is $3420 \mathrm{~kg}$ with displacement is $33.5 \mathrm{~mm}$ and specimen B2 is $5700 \mathrm{~kg}$ with displacement is $28.3 \mathrm{~mm}$.

2. The failure mechanism of specimen B1 due to connection failure, the gusset plate experienced local buckling and some screws were broken.
3. The failure mechanism of specimen B2 due to member failure, the compression member experienced local buckling and all connections were still in good condition.

4. Specimen B2 is better performance than specimen B1 due to the contribution of combination of screw and adhesive on connection.

5. By adding of thickness of gusset plate and combination screw and adhesive on gusset plate can make the structure becomes stronger and stiffer, and it can make the connections becomes stronger than members capacity.

\section{REFERENCES}

[1] P. R. Lewis, K. Reynold. C. Gagg, Forensic Material Engineering, New York: CRC Press, 2009.

[2] B. M. Imam, M. K. Chryssanthopoulos, A review of metallic bridge failure statistics, 5th International Conference on Bridge Maintenance, Safety and Management (IABMAS'10). Philadelphia, USA, 2010.

[3] C. G. Chiorean, Application of pushover analysis on reinforced concrete bridge model, $4^{\text {th }}$ European Workshop on the Seismic Behaviour of Irregular and Complex Structures, Thessaloniki, Greece, 2003.

[4] E. Yamaguchi, R. Okamoto, K. Yamada, Post-MemberFailure Analysis Method of Steel Truss Bridge, Procedia Engineering, 14, 2011, pp. 656-661.

[5] S. Charnrit, W. Krahothong, C. Pisitpaibool, Comparison between Analytical Results and Response of the Laboratory Scaled Truss Bridges under the Moving Car Load, International Transaction Journal of Engineering, Management, Applied Sciences \& Technologies, 5 (4), 2014, pp 287- 296.

[6] A. Manda, S. Nakamura, Progressive Collapse Analysis of Steel Truss Bridges, Proceedings of the School Engineering, Tokai University, Series E 35, 2010, pp. 27-34.

[7] A. Astaneh, Progressive Collapse of Steel Truss Bridges, the Case of I- 5W Collapse, $7^{\text {th }}$ International Conference on Steel Bridges, Guimaraes, Portugal, 2008.

[8] R. Pinho, C. Casarotti. S. Antoniou, A comparison of single-run pushover analysis techniques for seismic assessment of bridges, Engineering Structures, 30, 2007, pp. 1335-1345.

[9] S.N.R. Anwar, P. Suprobo, E. Wahyuni, Axial and flexural performance of adhesive connection on coldformed steel structure. International Journal of Technology, 4, 2015, pp. 699-708.

[10] B. Young, J. Chen, Column Tests of Cold-Formed Steel Non-Symmetric Lipped Angle Sections, Journal of Constructional Steel Research, 64, 2018, pp. 808-815. 
International Journal of Engineering Research and Technology. ISSN 0974-3154, Volume 13, Number 7 (2020), pp. 1757-1763

(C) International Research Publication House. https://dx.doi.org/10.37624/IJERT/13.7.2020.1757-1763

[11] B. Young, J. Yan, Channel Columns Undergoing Local, Distortional, and Overall Buckling, ASCE Journal of Structural Engineering, 128 (6), 2002, pp.728-736.

[12] R. Padmanaban, B.S. Suresh, Experimental Study on use of Cold Formed Steel Sections as Truss Members, International Journal of Innovative Technology and Exploring Engineering (IJITEE), 8, Issue-6S3, 2019, pp. 2278-3075.

[13] I. Komara, E, Wahyuni, P. Suprobo, K. Taşkin, Assessing the Tensile Capacity of Cold-Formed Steel Connections using Self-Drilling Screws and Adhesive Materials, International Journal on Advanced Science Engineering Information Technology, 8 (2), 2018, pp. 2088-5334.

[14] American Iron and Steel Institute, AISI Manual ColdFormed Steel Design 2002 Edition. AISI Specifications for the Design of Cold-Formed Steel Structural Members, 2003.

[15] Wei-Wen Yu, Cold-Formed Steel Design, John Wiley \& Sons, Inc., 2000. 